Філатова Оксана Аркадіївна, доктор медичних наук, доцент, профессор кафедри медичної психології ПрАТ «ВНЗ «Міжрегіональна Аадемія управління персоналом»; 02000, вул. Фрометівська, 2, м. Київ, Україна; hlaalu@ukr.net; +38 (067) 755-90-00

ORCID ID 0000-0001-8439-0779

\title{
ФОРМУВАННЯ КОМУНІКАТИВНОЇ КОМПЕТЕНТНОСТІ МЕДИЧНОГО ПСИХОЛОГА
}

\begin{abstract}
Анотація
Філатова О. А., доктор медичних наук, доцент, профессор кафедри медичної психології ПрАТ «ВНЗ «МАУП»; м. Київ, Україна. Формування комунікативної компетентності медичного психолога.

Ключові слова: комунікативна компетентність, медичний психолог, психотерапія, психокорекція, афіліація, емоційне вигоряння.

Постановка проблеми. Комунікативна компетентність медичного психолога є однією з складових його професійної діяльності, яка забезпечує можливість створення оптимальних терапевтичних стосунків в діаді «консультант - хворий» та обумовлює високий рівень психотерапевтичної та психокорекційної роботи.

Аналіз останніх досліджень та публікацій. Як свідчать дані вітчизняних та зарубіжних авторів, важливою умовою успішності комунікативної взаємодії між консультантом та пацієнтом стає оперування фахівцем цілим рядом як спеціальних медичних та психологічних знань, так і знань про правила організації спілкування, способах трансляції та адекватної інтерпретації
\end{abstract}


інформації, що надається, про особливості мовної поведінки пацієнтів, про потенційні комунікативні перешкоди, про засоби створення сприятливої психоемоційної атмосфери.

Формулювання мети статті. Розвиток комунікативної компетентності повинен починатися з перших кроків студента-медичного психолога на шляху оволодіння професією.

Виклад основного матеріалу. Виборка дослідження складала 214 медичних психологів віком від 28 до 42 років, яки висловлювали скарги, що під час клінічного інтерв'ю і протягом робочих сесій хворі виплескують весь накопичений негатив, агресію, роздратування. Катарсис, пережитий пацієнтом, обертається для психологів когнітивними перевантаженнями, емоційним виснаженням, підсвідомим бажанням відгородитися від лавини чужого не відреагованого матеріалу. Скаргами були: психоемоційне напруження, яке супроводжується тривогою, має динамічний характер, з коливаннями глибини переживань в залежності від загального тонусу i зовнішніх обставин; невдоволення собою, обраною професією; слабку комунікативну компетентність, недостатній розвиток фахової інтуїції. Обстежені відмічали в собі жорстку інтеріоризація обов'язків, ригідність рольового репертуару, невміння регулювати обставини діяльності, підвищене почуття відповідальності.

Висновки та перспективи подалыших досліджень. 3 метою підвищення рівню комунікативної компетентності використовуються особистісноорієнтовні методики, які спрямовані на розвиток соціальної перцепції, поглиблення емпатії, вироблення вміння протистояти стресовим ситуаціям за допомогою адаптивних копінг-стратегій.

\section{Аннотация}


Филатова О. А., доктор медицинских наук, доцент, профессор кафедры медицинской психологии ЧАО «ВУЗ «МАУП»; г. Киев, Украина. Формирование коммуникативной компетентности медицинского психолога.

Ключевые слова: коммуникативная компетентность, медицинский психолог, психотерапия, психокоррекция, аффилиация, эмоциональное выгорание.

Постановка проблемы. Коммуникативная компетентность медицинского психолога является одной из составляющих его профессиональной деятельности, которая обеспечивает возможность создания оптимальных терапевтических отношений в диаде «консультант - больной» и обусловливает высокий уровень психотерапевтической и психокоррекционной работы.

Анализ последних исследований и публикаций. Как свидетельствуют данные отечественных и зарубежных авторов, важным условием успешности коммуникативного взаимодействия между консультантом и пациентом становится оперирование специалистом целым рядом как специальных медицинских и психологических знаний, так и знаний о правилах организации общения, способах трансляции и адекватной интерпретации информации, которая предоставляется, об особенностях языкового поведения пациентов, о потенциальных коммуникативных препятствиях, о средствах создания благоприятной психоэмоциональной атмосферы.

Формулировка цели статьи. Развитие коммуникативной компетентности должно начинаться с первых шагов студента-медицинского психолога на пути овладения профессией.

Изложение основного материала. Выборка исследования составила 214 медицинских психологов в возрасте от 28 до 42 лет, которые высказывали жалобы, что во время клинического интервью и в течение рабочих сессий 
больные выплескивают на них весь накопленный негатив, агрессию, раздражение. Катарсис, пережитый пациентом, оборачивается для психологов когнитивными перегрузками, эмоциональным истощением, подсознательным желанием отгородиться от лавины чужого неотреагированного материала. Жалобами были: психоэмоциональное напряжение, которое сопровождается тревогой, имеет динамический характер, с колебаниями глубины переживаний в зависимости от общего тонуса и внешних обстоятельств; недовольство собой, избранной профессией; слабая коммуникативная компетентность, недостаточное развитие профессиональной интуиции. Обследованные отмечали в себе жесткую интериоризацию обязанностей, ригидность ролевого репертуара, неумение регулировать обстоятельства деятельности, повышенное чувство ответственности.

Выводы и перспективы дальнейших исследований. С целью повышения уровня коммуникативной компетентности используются личностноориентированные методики, направленные на развитие социальной перцепции, углубление эмпатии, выработки умения противостоять стрессовым ситуациям с помощью адаптивных копинг-стратегий.

\section{Annotation}

Filatova O. A., PhD, MD, Associate Professor, Professor of The Medical Psychology Department, The Private Joint-Stock Company "Higher Educational Institution "Interregional Academy of Personnel Management"; Kyiv, Ukraine. Formation of Communicative Competence of a Medical Psychologist.

Key words: communicative competence, medical psychologist, psychotherapy, psychocorrection, affiliation, emotional burnout.

Formulation of the problem. The communicative competence of a medical psychologist is one of the components of his professional activity, which provides the 
opportunity to create optimal therapeutic relationships in the dyad "consultant patient" and determines a high level of psychotherapeutic and psycho-correctional work.

Analysis of recent research and publications. According to the data of domestic and foreign authors, an important condition for the success of the communicative interaction between the consultant and the patient is the specialist's operation of a whole range of both special medical and psychological knowledge, as well as knowledge of the rules for organizing communication, methods of translation and adequate interpretation of the information that is provided, about the features of language patient behavior, about potential communicative obstacles, about the means of creating a favorable psycho-emotional th atmosphere.

Formulating the purpose of the article. The development of communicative competence should begin with the first steps of a student-medical psychologist on the path to mastering the profession.

The presentation of the main material. The sample of the study was 214 medical psychologists aged 28 to 42 years who complained that during clinical interviews and during working sessions, patients pour out all the accumulated negativity, aggression, irritation on them. The catharsis experienced by the patient turns for psychologists to cognitive overload, emotional exhaustion, a subconscious desire to isolate themselves from the avalanche of alien unreacted material. Complaints were: psycho-emotional stress, which is accompanied by anxiety, is dynamic in nature, with fluctuations in the depth of experience depending on the general tone and external circumstances; dissatisfaction with oneself, a chosen profession; poor communicative competence, insufficient development of professional intuition. The surveyed noted a strict internalization of responsibilities, the rigidity of the role repertoire, the inability to regulate the circumstances of the activity, and an increased sense of responsibility. 
Conclusions and prospects for further research. In order to increase the level of communicative competence, personality-oriented techniques are used to develop social perception, deepen empathy, and develop the ability to withstand stressful situations using adaptive coping strategies.

Ключові слова: комунікативна компетентність, медичний психолог, психотерапія, психокорекція, афіліація, емоційне вигоряння.

Постановка проблеми. Комунікативна компетентність медичного психолога є професійно значущою якістю. Фаховий функціонал медичного психолога передбачає в тій чи іншій мірі інтенсивне, диференційоване і тривале спілкування з хворими, їх родичами, медичним персоналом - від сестринської ланки і санітарних працівниць до головних лікарів, керівників медичних установ. Від уміння спілкуватися, встановлювати і розвивати взаємини 3 людьми, багато в чому залежить професійна успішність медичного психолога та його внутрішній стан. Психологічний комфорт при контактах 3 хворими, впевненість у собі як у фахівці та людині, панорамне мислення при відсутності жорстких шаблонів, допомагає точніше зібрати сімейний анамнез, отримати більш повне і глибоке уявлення про пацієнта. Вміння спілкуватися, або комунікативна компетентність, забезпечує взаєморозуміння, довіру у відносинах, ефективність у вирішенні поставлених завдань [1].

Аналіз останніх досліджень та публікацій. Якщо пацієнт довіряє своєму консультанту, не сумніваючись у правильності психологічної діагностики і адекватності психотерапевтичних заходів та психокорекції, то він буде ретельніше виконувати настанови, без побоювань пройде всі необхідні діагностичні та психотерапевтичні процедури. За відсутності психологічного контакту пацієнт, здебільшого, не вважає за потрібне дотримуватися рекомендацій консультанта, нерідко просить поради у інших психологів, 
займається самолікуванням у вигляді будь-яких «духовних практик», звертається до представників альтернативної медицини.

До речі, психологічна сторона відносин «хворий - медичний психолог» важлива і в умовах платного консультування, коли пацієнт виступає в ролі «замовника» та оплачує «послуги». У цьому випадку він орієнтується не тільки на «професіоналізм», рекламу навколо того чи іншого консультанта, а й на суто людські, особистісні якості: його зовнішність, стиль спілкування, мову, поведінкові патерни, наскільки він вселяє довіру і повагу, уважний і чуйний, розташовує до себе, чи викликає бажання й надалі спілкуватися. В окремих випадках (особливо це стосується хворих 3 невротичними розладами, онкохворих та пацієнтів з персоногенними хворобами), психологічні якості консультанта для хворого більш важливі, ніж професійні знання, уміння, навички.

Комунікативна компетентність передбачає не тільки наявність обов'язкових психологічних знань (наприклад, про типи особистості, про види переживань і реагування на стрес у різних людей залежно від темпераменту, про специфіку зв'язку між типами статури і особливостями психічного складу і т.п. ), а й сформованість деяких спеціальних навичок: вміння встановлювати контакт, вислуховувати, «читати» невербальну мову тіла, будувати бесіду, формулювати питання. Важливо також володіння спеціалістом власними емоціями, здатність зберігати впевненість і зовнішній спокій, контролювати свої реакції і поведінку в цілому. Адекватна комунікація передбачає правильне, емпатійне розуміння хворого і відповідне реагування на його поведінку. Незалежно від того, в якому душевному стані знаходиться пацієнт, чи відчуває він гнів або печаль, занепокоєння, тривогу або відчай, медичний психолог повинен вміти з ним взаємодіяти, адекватно будувати відносини, бути активним та конструктивно наполегливим, домагаючись вирішення професійних завдань. 
Фахова комунікація, як специфічний дискурс, відрізняється двокомпонентністю комунікативної мети, що включає інструментальну і терапевтичну складові. В основі комунікативної діяльності медичного психолога лежать деонтологічні принципи - поваги до пацієнта, правдивості, гуманізму. Спілкування в даній сфері цілеспрямовано організується фахівцем в рамках якої-небудь 3 вироблених і прийнятих в соціумі інтерактивних моделей (патерналістської, споживчої (в умовах платної медицини), моделі інформованого прийняття рішення (або спільного прийняття рішення) і підходів (нозоцентрованого або паціентцентрованого).

Формулювання мети статті. Розвиток комунікативної компетентності повинен починатися 3 перших кроків студента-медичного психолога на шляху оволодіння професією.

Виклад основного матеріалу. Виборка дослідження складала 214 медичних психологів віком від 28 до 42 років, яки висловлювали скарги, що під час клінічного інтерв'ю і протягом робочих сесій хворі виплескують весь накопичений негатив, агресію, роздратування. Катарсис, пережитий пацієнтом, обертається для психологів когнітивними перевантаженнями, емоційним виснаженням, підсвідомим бажанням відгородитися від лавини чужого не відреагованого матеріалу. Скаргами були: психоемоційне напруження, яке супроводжується тривогою, має динамічний характер, з коливаннями глибини переживань в залежності від загального тонусу і зовнішніх обставин; невдоволення собою, обраною професією; слабку комунікативну компетентність, недостатній розвиток фахової інтуїції.

Обстежені відмічали в собі жорстку інтеріоризація обов'язків, ригідність рольового репертуару, невміння регулювати обставини діяльності, підвищене почуття відповідальності. 
У зв'язку з цим, професійно значущою якістю медичного психолога $є$ комунікативна толерантність (як один 3 аспектів комунікативної компетентності), тобто - терпимість, поблажливість та ін. Комунікативна толерантність показує, в якій мірі консультант контейнує суб'єктивно небажані, неприйнятні для нього індивідуальні особливості пацієнтів, негативні якості, небажані вчинки, звички, чужі стилі поведінки й стереотипи мислення. Хворий може викликати різні почуття, симпатію або антипатію, навіть, внутрішній гнів - але в кожному разі психологічна підготовка консультанта повинна допомогти впоратися з ситуацією, запобігти конфлікту або виникненню неформальних відносин, коли замість рольової структури «консультант - хворий» виникають відносини близької дружби, надмірної відвертості збоку фахівця, залежності, любові. Комунікативна компетентність у професійній діяльності означає вміння не тільки психологічно правильно будувати відносини з хворим, але і здатність у процесі цих відносин залишатися в рамках професійної етики.

Психологічні характеристики, що формують комунікативну компетентність, тобто вміння спілкуватися, встановлювати і розвивати взаємини 3 іншими людьми, формуються в процесі взаємодії 3 оточуючими, у міру накопичення життєвого та професійного досвіду у різних соціальних ситуаціях, виконання різноманітних видів діяльності. У спілкуванні формуються і виявляються властивості особистості медичного психолога: тривожність, невпевненість, агресивність, ригідність і т. д. На цьому тлі іноді дисгармонійно розвивається і комунікативна компетентність.

Важливою умовою успішності комунікативної взаємодії між консультантом та пацієнтом стає оперування фахівцем цілим рядом як спеціальних медичних та психологічних знань, так і знань про правила організації спілкування, способах трансляції та адекватної інтерпретації інформації, що надається, про особливості мовної поведінки пацієнтів, про 
потенційні комунікативні перешкоди, про засоби створення сприятливої психоемоційної атмосфери. Перераховані види знань дають уявлення про особливості здійснення комунікації в сфері медико-психологічної допомоги в їі прототипній формі - спілкуванні психолога і пацієнта, що позначається в особливому професійному дискурсі.

Різні аспекти усного медико-психологічного дискурсу активно розробляються західними та американськими соціолінгвістами, послідовниками дискурс- аналізу та аналізу мови, етнографами мови, соціологами і психологами [2]. Інформація, отримана в ході вивчення усного медико-психологічного дискурсу, і по сьогодні має фрагментарний, несистематизований характер. Спроби вивчення його окремих аспектів не дозволили в повному обсязі визначити модель комплексного аналізу дискурсу, виробленого лікареммедичним психологом i пацієнтом, виявити його екстралінгвістичну, когнітивну, жанрову специфіку, а також основні джерела комунікативних перешкод в ньому.

В основі формування комунікативної компетентності лежить ще одна психологічна характеристика особистості - прагнення перебувати разом 3 іншими людьми, належати до якоїсь соціальної групи, встановлювати емоційні зв'язки з оточуючими, бути включеним в систему міжособистісних взаємин. В конфліктних ситуаціях, у разі загострення взаємин, присутність поруч емоційно близьких людей стабілізує картину світу i самооцінку, зміцнює позиції, дозволяє більш точно і адекватно реагувати на зовнішні події. Відомо, що в стані тривоги підвищується потреба в інших людях, в їх співучасті; сама їх присутність поруч значно знижує рівень тривоги, зменшує інтенсивність негативних переживань [3]. Для будь-якої людини наявність соціальних зв'язків є настільки важливою, що вже тільки їх недостатність вважається можливою причиною розвитку стресу. Ця невід’ємна риса - потреба в інших людях, 
прагнення до взаємодії 3 ними, в соціально-психологічній літературі позначається терміном «афіліація» - потреба людини бути в товаристві інших, прагнення до приєднання [4]. Внутрішньо (психологічно) афіліація виступає у вигляді почуття прихильності і вірності, а зовні - у товариськості, бажанні співпрацювати 3 іншими людьми, постійно перебувати разом 3 ними, в особливостях невербальної поведінки. Titchener визначає аффилиацию як певний клас соціальних взаємодій, що мають повсякденний, і в той же час, фундаментальний характер. Зміст таких взаємодій полягає в «спілкуванні зі знайомими, малознайомими і незнайомими людьми, і така їхня підтримка, що приносить задоволення, захоплює i збагачує» [5]. У роботі медичного психолога, що відрізняється тривалістю i інтенсивністю різноманітних соціальних контактів, ця риса допомагає зберегти живе зацікавлене ставлення до пацієнтів, прагнення допомагати їм і співпрацювати з ними, а також захищає від професійних деформацій, байдужості і формалізму, утримує від такого погляду на хворого, коли він починає розглядатися як безособове анонімне «тіло», частина якого потребує «терапевтичного ремонту» [6].

Інша психологічна характеристика, що забезпечує комунікативну компетентність консультанта - це емоційна стабільність, врівноваженість за відсутності імпульсивності, надмірної емоційної експресивності, із збереженням контролю над емоційними реакціями i поведінкою в цілому. Емоційна стабільність допомагає спеціалісту у взаєминах 3 хворими та їх родичами уникати «психологічних зривів», конфліктів. Інтенсивні емоційні реакції не тільки руйнують довіру хворого, лякають і насторожують його, а й астенізують, втомлюють самого консультанта. Навпаки, душевна рівновага фахівця, його спокійна доброзичливість, емоційна стабільність викликають у пацієнта відчуття надійності, сприяють встановленню довірливих відносин. У ситуації хвороби, як правило, у кожної людини підвищується рівень тривоги, що 
призводить до посилення емоційної нестійкості, дратівливості, плаксивості, запальності, спалахах агресивності. У більшості випадків спостерігається також астенія - в якості однієї 3 найбільш поширених і неспецифічних форм психічного реагування на різноманітні внутрішні і зовнішні патогенні фактори: психогенної, травматичної, соматогенної та іншої природи. Хворі, 3 їх нестабільною психікою, тривожністю, невпевненістю, занепокоєнням, лабільністю емоційних реакцій, потребують стабілізуючого впливу збоку медичного психолога. Особливо це важливо для хворих з важкими психічними розладами. Так, одним з можливих психологічних способів підвищення рівня соціальної адаптації хворих на шизофренію $є$ вербалізація різноманітних вражень і уявлень, їх систематизація та узагальнення, що міняють картину світу хворого і стабілізують його стан.

Психологічною якістю, що забезпечує адекватну комунікацію в системі взаємовідносин «консультант - хворий», $є$ також емпатія, здатність до співчуття, співпереживання, своєрідна психологічна «включеність» у світ переживань та сподівань хворого. Сучасне розуміння емпатії як осягнення емоційного стану, проникнення у внутрішній світ іншої людини, припускає наявність трьох іiі видів: емоційної емпатії, заснованої на механізмах ототожнення та ідентифікації; когнітивної (пізнавальної) емпатії, що базується на інтелектуальних процесах (порівнянні і аналогіï), і предикативної емпатії, що виявляється в здатності до прогностичного уявлення про іншу людину, заснованого на інтуїції. Емоційна співучасть допомагає встановити довірчий психологічний контакт з хворим, отримати більш повну і точну інформацію про нього, його стан, надати впевненість у компетентності фахівця, в адекватності здійснюваного ним діагностично-корегувального процесу, вселити віру в одужання. Емпатичні якості медичного психолога можуть бути корисними у випадках невідповідності продемонстрованих хворим суб'єктивних ознак тих чи 
інших симптомів об'єктивній клінічній картині захворювання: при агравації, дисимуляції і анозогнозії, а також у разі симулятивного поведінки.

Психологічною характеристикою, що бере участь у формуванні комунікативної компетентності медичного психолога, $\epsilon$ i сенситивність до відторгнення. Здатність сприймати негативне ставлення оточуючих, зокрема, пацієнтів, яке може виникати на певних етапах лікування, надає консультанту своєрідного «зворотного зв'язку», що дозволяє йому корегувати свою поведінку у взаєминах 3 хворим. Водночас, сенситивність до відторгнення не повинна бути занадто високою, інакше вона сприяє зниженню самооцінки консультанта, блокує його афіліативну потребу, i в цілому знижує його адаптивні i компенсаторні можливості. Висока чутливість до негативного ставлення з боку хворого та його родичів змушує фахівця сумніватися у своїй професійній компетентності. Подібні сумніви, в свою чергу, можуть реально відбитися на якості роботи. Нерідко (у молодих спеціалістів) невпевненість у власній професійній спроможності стає причиною психічної травматизації і призводить до психоемоційних розладів.

Існують певні психологічні особливості, що знижують комунікативну компетентність медичного психолога. Його професійна діяльність завжди пов'язана з розробкою стратегії і тактики психотерапевтичного впливу i, отже, вимагає вміння прогнозувати події, передбачаючи можливі варіанти розвитку захворювання, ускладнення, ятрогенії, наслідки фармакологічного лікування. У зв'язку 3 цим важливою $\epsilon$ наявність у медичного психолога такої характеристики, як тривожність, яка впливає на його прогностичні можливості, виконуючи залежно від ступеня вираженості як адаптивну, так і дезадаптивну роль. Тривога - це емоція, спрямована в майбутнє, що пов'язана 3 прогнозуванням, передбаченням, очікуванням можливих невдач, $з$ формуванням відповідних внутрішніх команд і настанов. Як правило, емоція тривоги виникає 
в ситуаціях невизначеності і очікування, обумовлених дефіцитом інформації, часу на роздуми і важкопрогнозованим результатом. Легка ступінь тривоги (занепокоєння) - суто людська реакція на невизначеність, що сигналізує про можливу небезпеку і виконує в цьому випадку адаптивну функцію. Мобілізація під впливом тривоги адаптивних, компенсаторних i захисних механізмів дозволяє більш ефективно протистояти можливій небезпеці. Тривожність як властивість особистості дозволяє фахівцю чуйно реагувати на зміни в стані пацієнта і вчасно вживати необхідних психотерапевтичних заходів. Хворим це сприймається як розуміння з боку консультанта, його не тільки професійна, але й емоційна підтримка, що підвищує ефективність терапевтичної комунікації. Однак, інтенсивна ступінь емоції тривоги (страх, паніка, жах) виконує по відношенню до пізнавальної діяльності дезорганізуючу, руйнуючу функцію, паралізує продуктивну роботу психічних процесів. Інтенсивна тривога заважає адекватно оцінити ситуацію, визначити можливі варіанти їі розвитку і вибрати найбільш правильне за даних обставин рішення. Страх, паніка у медичного психолога переривають його комунікацію з пацієнтом, руйнують психологічний контакт між ними. Тривога спеціаліста транслюється хворому і додатково дезорганізує його. Під впливом тривоги можуть порушуватися різні функції організму, який реагує, наприклад, порушеннями сну, зниженням апетиту, різноманітними вегетативними коливаннями. Підвищена тривожність відзначається у більшості пацієнтів, тому їі посилення під впливом страху, пережитого консультантом, вкрай не бажане. У цьому випадку хворий може відчути безнадійність свого стану, перестає вірити в можливість одужання. Консультанти з високою особистісною тривожністю, схильні реагувати на будьякі зміни іiі підвищенням, можуть створювати навколо хворого ятрогенно небезпечну обстановку. 
Іншою характеристикою медичного психолога, здатною зруйнувати його комунікацію з пацієнтом, може бути депресивність. Якщо емоція тривоги спрямована в майбутнє, то депресія пов'язана з переживанням минулого, коли в уяві знов і знов виникають образи пережитих конфліктів, психотравмуючих подій. Минуле представляється суцільним ланцюгом невдач і неприємностей, формуючи відчуття безвиході, безнадії, яке проектується в майбутнє. Втрачається перспектива, життя забарвлюється переживанням власної неспроможності, неповноцінності. Медичний психолог, що має схильність до депресивних реакцій, не викликає довіри хворого. Спостерігаючи, як консультант на будь-яку, навіть незначну подію, неточність, помилку реагує почуттям провини, не може опанувати себе і гідно вийти 3 неприємного становища, хворий починає підозрювати його в некомпетентності, перестає йому вірити. Занурений у власні переживання, фахівець може навіть не помітити поліпшення в стані свого пацієнта, вчасно не підтримати його, підкресливши симптоми одужання i, навпаки, «заражає» того тужливою безнадією, руйнуючи позитивні ефекти проведеної терапії.

Ще одна психологічна характеристика, що утруднює встановлення довірчих відносин «консультант - хворий» - це глибока інтровертованість фахівця. Інтроверсія, за визначенням К. Юнга, характеризується як спрямованість суб'єкта на самого себе, зверненість до власних відчуттів, переживань, пізнавальних конструкцій, що по-своєму, суб'єктивно, інтерпретують навколишній світ [7]. Інтроверт орієнтується на власні цінності, ідеали, переконання, моральні та етичні норми. Інтровертована особистість, занурена в свій психологічний світ, цілком зайнята собою, своїми почуттями, ідеями, враженнями, мало цікавиться іншими людьми, виявляючи безпорадність у ситуації, що вимагає взаємодії та співпраці з оточуючими. Як правило, інтровертованість супроводжується недоліком афіліації, чуйності, тактовності в 
міжособистісних відносинах, низьким рівнем емпатії з недостатньою здатністю відгукуватися на біль і страждання іншого, зменшувати його занепокоєння і тривогу. Ці якості можуть суттєво знизити комунікативну компетентність медичного психолога, виступаючи в ролі «комунікативного бар'єру», що перешкоджає ефективному спілкуванню. Інтровертованість, виражена в значній мірі, ускладнює встановлення психологічного контакту з хворим, взаємодію 3 ним, не забезпечує необхідного ступеня емоційної підтримки.

Багатовіковий досвід майстерного вміння спілкуватися 3 хворими, що уявляє з себе мистецтво, формує нашу уяву про те, що воно починає створюватися ще в процесі навчання в медичному вузі, згодом - під час самостійного професійного спілкування в умовах клініки, стикаючись 3 людьми різних психологічних якостей, різного віку, рівню освіти, соціальної та професійної приналежності. Спочатку, на ранніх етапах навчання, починаючи взаємодіяти з хворими, майбутні медичні психологи часто несвідомо, за механізмом наслідування, копіюють стиль поведінки тих викладачів, що викликали в них особливу повагу, на чию думку вони орієнтувалися, переймаючи у них манеру спілкування з хворими, особливості їх невербальної поведінки (жести, мімічні реакції, пози, манеру проводити клінічне інтерв’ю), інтонації, запозичуючи з їх словника ключові фрази (часто - першу фразу, з якої починається контакт 3 пацієнтом та останню фразу 3 заключними узагальнюючими формулюваннями). По мірі накопичення досвіду професійного спілкування, молодий фахівець вже усвідомлено починає використовувати різноманітні психологічні навички, які полегшують встановлення контакту з хворим. Чим більше стаж роботи медичного психолога, тим уважніше він ставиться до психологічних аспектів діагностичного та психотерапевтичного процесу, підвищенню рівня комунікативної 
компетентності, що неодмінно забезпечує більш високу ефективність професійної взаємодії.

Слід пам'ятати, що адаптація молодого медичного психолога до професійної діяльності займає близько двох років. Як правило, цей час необхідний йому для того, щоб відчути себе впевнено в новій соціальній ролі, виробити індивідуальний професійний «імідж», придбати певний репертуар навичок, алгоритмів дії в стандартних професійних ситуаціях. На початку самостійної роботи молодий спеціаліст зазвичай ще не відчуває себе цілком упевнено, орієнтуючись на більш досвідчених колег, до допомоги яких він вдається в складних або відповідальних випадках. Триває пошук інформації, тренування професійних навичок з отриманням зворотного зв'язку (схвалення, заохочення з боку старших), інтенсивне спілкування з молодими початківцямиколегами, що забезпечує обопільну емоційну підтримку. Цей пізнавальний елемент професійної адаптації можна позначити як вдосконалення професійних знань, умінь, навичок.

Іншою, емоційною складовою професійної адаптації медичного психолога, є вироблення навички визначення тієї міри емоційної «включеності» у ситуацію хворого, яка необхідна в кожному конкретному випадку професійного спілкування. Цей компонент адаптації пов'язаний з емпатією, 3 «дозуванням» емоційної залученості в процесі міжособистісної взаємодії 3 хворим. У перші роки самостійної професійної діяльності молодий фахівець в прагненні якомога краще допомогти хворому, переживає підвищену відповідальність за свої дії - внаслідок недостатньої впевненості в своєму професіоналізмі, відчуває надмірні емоційні навантаження. Така надлишкова «включеність» в світ переживань хворого, підвищений рівень тривоги як реакція на ситуацію невизначеності, невпевненості; побоювання і настороженість щодо можливих наслідків призначеного лікування, призводять 
до хронічних емоційних перенавантажень. У молодого фахівця знижуються адаптивні і компенсаторні можливості. Внаслідок постійної перевтоми можливі порушення імунітету, часті простудні захворювання, загострення хронічних соматичних розладів. Виникає «синдром емоційного вигоряння» як специфічна професійна деформація осіб, що працюють в тісному емоційному контакті 3 пацієнтами при наданні медичної допомоги [8]. «Синдром емоційного вигоряння» суб'єктивно виявляється в почутті психічного виснаження, внаслідок чого знижується ефективність професійної взаємодії: консультант вже не може повністю віддаватися роботі, як це було колись, що впливає на самооцінку; його діяльність суб'єктивно сприймається ним як недостатньо успішна. Можлива поява негативного ставлення до пацієнтів, що сприймаються як джерело хронічної психічної травматизації. Взаємодіючи з хворим, такий консультант перестає брати до уваги психологічні феномени, пов'язані 3 захворюванням - внутрішню картину хвороби $з$ іiї складною структурою, механізми психологічного захисту і копінг-поведінку, не реагує на тривогу пацієнта, не помічає його депресивних, суїцидальних тенденцій. У висловлюваннях медичного психолога про своїх хворих можуть з'явитися цинізм, холодна байдужість i, навіть, ворожість. Ця своєрідна «криза» професійної діяльності може повторюватися час від часу. Хворі перестають звертатися до такого спеціаліста за допомогою, іноді віддаючи перевагу менш досвідченим і компетентним, але більш доброзичливим. У період подібної кризи фахівець потребує відпочинку, зміні діяльності, психологічного «розвантаження», психотерапевтичної допомоги. $\mathrm{У}$ жінок-консультантів емоційне виснаження розвивається більш частіше, ніж у колег-чоловіків. В персонологічному плані таких жінок описують як співчуваючих, гуманних, м'яких, захоплених таємницями професії, схильних ідеалізувати оточуючих 
людей. Одночасно, це особи емоційно нестійкі, 3 коливаннями настрою, інтроверсією, здебільшого позбавлені достатньої емоційної підтримки.

По мірі «професійного дорослішання» медичний психолог навчається «дозувати» ступінь емоційної залученості в процесі професійного спілкування. Емоційна складова найбільш важлива на початку спілкування з хворим, при встановленні довірчої дистанції. Надалі, емоційні компоненти можуть бути свідомо значно зменшені. Інтенсивність емоційних контактів 3 пацієнтом підвищується лише на окремих, найбільш значущих етапах діагностики i психотерапії. Роль емоційної взаємодії зростає в ситуаціях виникнення загрози життю хворого (суїцидні тенденції), при спілкуванні 3 депресивними пацієнтами, а також при контактах з хворими, які перенесли важку психічну травму (смерть близької людини, втрата працездатності, розлучення).

Ще один компонент професійної адаптації пов'язаний з формуванням «професійного іміджу» - як важливого інструменту фахової діяльності. Один 3 найбільш значущих його елементів - впевнена поведінка медичного психолога, його синтонність. За будь-яких, найнесподіваніших, найнебезпечніших ситуацій, навіть якщо консультант шокований, наляканий, пригнічений допущеною помилкою - він не повинен показувати своєї розгубленості хворому. Упевнений стиль поведінки допомагає сформувати у хворого «терапевтичну ілюзію» абсолютної компетентності фахівця, його здатності контролювати ситуацію і визначати прогноз, що дозволяє пацієнту зберігати віру в благополучний результат психотерапевтичного втручання.

Висновки та перспективи подальших досліджень. Таким чином, ми можемо зробити висновок, що оволодіння комунікативною компетентністю надає фахівцю можливість створити оптимальні умови для консультативного процесу, зекономити час на першому етапі клінічного інтерв'ю, викликати у хворого бажання продовжувати спільну роботу. Впевнена поведінка допомагає 
забезпечити довіру хворого, вселити в нього надію, тим самим активізуючи захисні і компенсаторні механізми. Іншими складовими «професійного іміджу» $€$ характеристики невербальної поведінки: відкриті пози, що розташовують до спілкування; комунікативні та експресивні жести, розраховані на створення певного враження; мімічні реакції, що виражають доброзичливість, спокійну впевненість; міжособистісна дистанція, що відображає ступінь емоційної близькості в кожен момент спілкування залежно від поставлених тактичних завдань. Важливим $є$ і зовнішній вигляд медичного психолога, особливості його мови: довірчої, владної i, водночас, спокійної, 3 впевненою інтонацією, плавністю вимови, добре побудованою лексикою. Всі ці компоненти підвищують ступінь довіри і впевненість у професійній компетентності медичного психолога.

\section{Список використаних джерел}

1. Болотова А. К. Психологія комунікацій / Болотова А. К., Жуков Ю. М. М.: Вид. Дім ВШЕ, 2015. - 496с

2. Чеботнікова Т. А. Мовна поведінка як один із способів актуалізації особистості / Т. А. Чеботнікова //Вісник Челябінського державного університету, 2017.- № 28 (243).- С. 138-143.

3. Психологічний вплив у міжособистісній та масовій комунікації [ред. Журавльов А. Л., Павлова Н.Д.]. - Вид-во ІП РАН, 2014.- 400с.

4. Андрєєва Г.М. Соціальна психологія / Г. М. Андрєєва.- М.: Аспект-Прес, 2016.-363c.

5. Titchener E. (2005) Reviewing The Arts (Lea's Communication Series).- 184 p.

6. Maslach C., Jackson S. E. The Maslach Burnout Inventory. Palo Alto, CA: Consulting Psychologists Press, 1986.

7. Юнг К.Г. Психологічні типи / К. Г. Юнг.- М.: Академпроект, 2019 - 538с. 
8. Бабанов С. А. Професійні фактори і стрес: синдром емоційного вигорання

/ С. А. Бабанов // Важкий пацієнт.- 2009.- № 12.- С.10-13.

\section{References.}

1. Bolotova, A. K. Zhukov, YU. M. (2015), "Psikhologiya kommunikatsiy" [Psychology of communications] - Izdatel'skiy Dom VSHE, Moscow, Ru.

2. Chebotnikova, T.A.(2017), "Language behavior as one of the ways to actualize the personality", Vestnik Chelyabinskogo gosudarstvennogo universiteta, vol 28 (243), pp. 138-143, Ru.

3. "Psikhologicheskoye vozdeystviye $v$ mezhlichnostnoy $i$ massovoy kommunikatsii" [Psychological influence in interpersonal and mass communication] [red. Zhuravlev, A.L. Pavlova, N.D.], (2004), Izd-vo IP RAN, Moscow, Ru.

4. Andreyeva, G. M. (2016), "Sotsial'naya psikhologiya”, [Social psychology], Aspekt-Press, Moscow, Ru.

5. Titchener, E. (2005) Reviewing The Arts (Lea's Communication Series), En.

6. Maslach, C. Jackson, S. E. (1986), “The Maslach Burnout Inventory”. Palo Alto, CA: Consulting Psychologists Press, En.

7.Yung, K.G. (2019), "Psikhologicheskiye tipy" [Psychological types], Akademproyekt, Moscow, Ru.

8. Babanov, S.A. (2009), "Professional factors and stress: emotional burnout", Trudnyy patsiyent, vol. 12, pp. 10-13, Ru. 